\title{
Indian health planners shun insecticides in disease control
}

New Delhi

AFTER having spent over 3,000 million dollars on insecticides in the past 25 years, India is convinced that it has lost its battle against mosquito-borne diseases. Now planners are testing an alternative control strategy based on environmental management with community participation - but no insecticides.

The Indian Council of Medical Research (ICMR) is spearheading the new integrated vector management (IVM) scheme, based on a combination of biological control and environmental measures such as cleaning clogged drains and filling stagnant pools. Results of the five demonstration projects conducted so far are encouraging and hold out hope that the approach may provide the final solution.

With half of its health budget spent on malaria prevention India is running the biggest anti-malaria programme in the

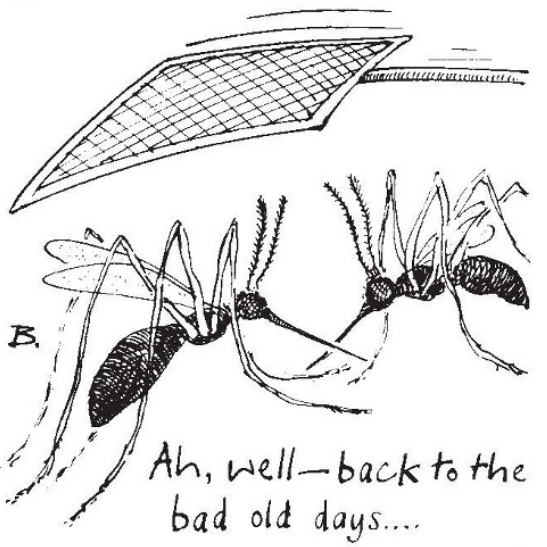

world. Insecticides and drugs lie at the heart of the programme but have brought with them a host of new problems. Bottled milk has been found containing 9.5 times the permissible limit of DDT, and samples of human milk collected in Punjab contained 21 times the acceptable limits of various pesticides. At the same time the development of insecticide resistance has made new and more expensive imports necessary.

The new strategy aims "to strike a balance between man, mosquitos and the environment in such a way that the vector population is stabilized at a very low level at which disease transmission ceases to occur", says Dr P.K. Rajagopolan, director of the Vector Control Research Centre (VCRC) in Pondicherry, one of the ICMR institutes. VCRC applied its new strategy in the filaria-endemic coastal township of Pondicherry, where mosquitos were breeding in thousands of cesspits, ponds and wells, a large swamp and 100 $\mathrm{km}$ of open drains. First, VCRC launched a massive health-education campaign aimed at enlisting public cooperation in cleaning up the town. Within two years $15,000 \mathrm{~m}^{2}$ of surface water were eliminated and wells stocked with larvae eating fish. The swamp was converted into a park. In 1986, when the project ended, there were only three new cases of filariasis in the whole of Pondicherry and the number of mosquito bites, according to a VCRC report, "dropped by 90 per cent".

Recently ICMR applied its new app- roach to an industrial township (population 45,000) in Hardwar on the banks of the Ganges in Uttar Pradesh. In its interim report ICMR said that within 18 months of launching the project, mosquito densities fell by half while cases of malaria dropped from 250 to 32 . That improvement was achieved simply by filling ditches with flyash (an industrial by-product), cleaning drains and covering overhead tanks. The 30,000 dollars spent on environmental control was just five per cent of what industry would otherwise have lost from paying for sick leave and hospitalization of workers with malaria.

K.S. Jayaraman

\section{London}

A SOVIET automation expert has described the training of nuclear power station personnel as "amateurish". Writing in the daily Sotsialisticheskaya Industriya, R. Tsiptyura, described as a department head at the Promavtomatika scientific and production association, noted that although the responsibility of operating a power station control board is analogous to that of an airline pilot, neither the USSR Ministry of Power and Electrification nor the USSR Ministry of Nuclear Power has a training scheme similar to those used in aviation. For nuclear stations, he said, training is carried out by on-the-job and understudy methods.

Recently, he notes, there have been some changes: the Novovoronezh training and instruction centre now has simulators for the VVER-400 and VVER-1000 reactors, and this year a "technological process control station", providing training for RBMK (Chernobyl-type) reactors will come into operation at the Smolensk nuclear power station.

In spite of these apparent changes, however, he said, the two relevant ministries have no proper training system, and "incredible" things sometimes happen; such as people who have no real connection with the operator's job being sent for training, simply to "fulfil the training plan" in gross figures.

Simulator training was one of the measures promised by the Soviet delegation at the post-Chernobyl accident review conference in August 1986. Had the Chernobyl crew been trained in simulated accidents, the Soviet team admitted, they would not have overridden the strict operational rules so lightly.

But bad operator procedures are not the monopoly of the Soviet nuclear industry - Tsiptyura noted that at the Ekibastuz Hydro-storage power station during 19811984 there were 366 accidents due exclusively to operator error. But when the power-production sector was split, by hiving off nuclear power into a separate ministry, the responsibility for simulator training was likewise divided. The present simulator training units have been developed by individual power stations. Tsiptyura suggested that efforts should rather be coordinated into a network of "interdepartment science and production collectives" subordinate to some interdepartmental body such as the State Committee for Science and Technology, or the USSR Council of Ministers Bureau for the Fuel and Power Complex.

"Interdepartmental collectives" is one of the catch-phrases of perestroyka (restructuring). When first urged by $\mathrm{Mr}$ Gorbachev in June 1985, they were intended to overcome the bureaucratic and inter-sector delays bedevilling the Soviet economy. So far, however, anecdotal evidence suggests that they are encountering bureaucratic problems of their own. Tsiptyura may therefore be over-optimistic in suggesting that such a network would necessarily resolve the situation.

Vera Rich

\section{Tropical fruits}

\section{London}

Two funding organizations have joined forces to help finance the twinning of institutes in developed and developing countries that share a research interest in tropical diseases. Up to $\$ 2$ million a year will be provided to worthy partners under the new scheme, which is financed by the Rockefeller Foundation and the UNDP/ World Bank/WHO Special Programme for Research and Training in Tropical Disease, under its new director, Tore Godal. Value for money will be judged by the scientific productivity of the joint venture and the extent to which it promotes intellectual self-reliance of the weaker partner. But there will be maximum flexibility on what the money is spent on, says Godal. 